\title{
Modele sukcesji zarządzania w przedsiębiorstwach rodzinnych
}

\author{
Dr hab. Wojciech Popczyk, prof. UŁ (iD \\ Uniwersytet Łódzki, Wydział Zarządzania \\ Katedra Strategii i Zarządzania Wartością Przedsiębiorstwa
}

\section{Wprowadzenie}

Temat sukcesji w przedsiębiorstwach rodzinnych jest najbardziej popularny w piśmiennictwie naukowym poświęconym problematyce funkcjonowania tych podmiotów i zarządzania nimi ${ }^{1}$. Ta popularność wynika z kluczowego znaczenia planowania i implementacji transferu międzypokoleniowego zarządzania dla wzrostu i rozwoju biznesu w długim okresie, dla generowania i wykorzystywania zasobów niematerialnych, których nośnikiem jest rodzina właścicielska, w procesie budowania i powiększania przewagi konkurencyjnej ${ }^{2}$. Niestety, sukcesja zarządzania jest procesem złożonym, wieloetapowym, wielowymiarowym, w zdecydowanej większości przypadków kończącym się niepowodzeniem. Z rąk pierwszego pokolenia do drugiego pokolenia rodziny przechodzi $30 \%$ przedsiębiorstw rodzinnych, $10-15 \%$ do trzeciego pokolenia, a tylko $3-5 \%$ do czwartego ${ }^{3}$. Z naturalnych i pragmatycznych przyczyn naukowcy, konsultanci i praktycy poszukują rozwiązań,

1 J.J. Chrisman, J.H. Chua, P. Sharma, Current trends and future directions in family business management studies: Toward a theory of the family firm, „Coleman White Paper Series”, Coleman Foundation and USA Association of small Business and Entrepreneurship, Madison 2003, s. 1-60; J.H. Chua, J.J. Chrisman, P. Sharma, Succession and non-succession concerns of family firms and agency relationship with nonfamily managers, „Family Business Review” 2003, vol. 16(2), s. 221-235.

2 T.G. Habbershon, M.L. Williams, A resource-based framework for assessing the strategic advantages of family firms, „Family Business Review” 1999, vol. 12(1), s. 1-25; T.G. Habbershon, M.L. Williams, I.C. Macmillan, A unified systems perspective of family firm performance, „Journal of Business Venturing” 2003, vol. 18(4), s. 451-465; J. Hoffman, M. Hoelscher, R. Sorenson, Achieving sustained competitive advantage: A family capital theory, „Family Business Review” 2006, vol. 19(2), s. 135-145; W. Popczyk, The structure and creating of family social capital in business, [w:] New Challenges of Economic and Business Development, University of Latvia, Riga 2018, s. 676-685.

3 C. Wood, The Surprising Stats about Succession in Family Business, „All Strategy” 2018, https://www.allstrategy.net/the-surprising-stats-about-succession-in-family-business/ (dostęp: 1.06.2019). 
strategii czy modeli, które zwiększą prawdopodobieństwo sukcesu w tym obszarze i tym samym prawdopodobieństwo zachowania ciągłości zarządzania, postępu w zakresie wzrostu i rozwoju oraz efektywności podmiotów rodzinnych.

Celem rozdziału jest identyfikacja koncepcji naukowych, które pomogą zrozumieć powody niepowodzeń sukcesyjnych w firmach rodzinnych oraz prezentacja najlepszych rozwiązań sukcesyjnych na świecie, zwiększających prawdopodobieństwo transferu międzypokoleniowego (lub pozarodzinnego) zarządzania w małych, średnich i dużych przedsiębiorstwach rodzinnych.

Wielkość przedsiębiorstwa determinuje przebieg i specyficzne zagrożenia sukcesji. Jako rezultat własnych poszukiwań literaturowych i badawczych autor prezentuje antropologiczną koncepcję struktury rodziny, aby w drodze dedukcji wyjaśnić przyczyny i potencjalne źródła niepowodzeń w planowaniu i przebiegu sukcesji w przedsiębiorstwach rodzinnych, zwłaszcza małych i średnich, oraz konstruuje model efektywnej sukcesji w dużych przedsiębiorstwach rodzinnych na podstawie dobrych praktyk, zidentyfikowanych i opisanych w literaturze przedmiotu na świecie.

W każdej z czterech opisywanych w pierwszej części opracowania struktur rodziny proces socjalizacji młodego pokolenia przebiega w innych uwarunkowaniach kulturowych, co wywołuje zróżnicowane postawy przedstawicieli młodego pokolenia rodziny i seniorów do sukcesji biznesu prowadzonego przez rodzinę przedsiębiorczą. Autor proponuje rozwiązania systemowe, które mogłyby przeciwdziałać zagrożeniom, głównie w małych i średnich przedsiębiorstwach, odwołując się do prawidłowości antropologicznych.

Zaprezentowany w drugiej części rozdziału model sukcesyjny został zbudowany na bazie pozytywnych doświadczeń, dobrych, skutecznych praktyk sukcesyjnych w przedsiębiorstwach rodzinnych średnich i dużych, globalnych, wielopokoleniowych, zidentyfikowanych podczas aktywności konsultingowej i badawczej przez takie instytucje jak Cambridge Institute for Family Enterprise, FORBS, Spencer Stuart, Harvard Business School. Zasadnicze podobieństwa tych jednostkowych propozycji stały się podstawą stworzenia modelu, który może posłużyć za benchmark dla konkretnych przypadków sukcesyjnych. Różnice między propozycjami mogą stanowić komplementarną wartość dodaną dla tak powstałego modelu-benchmarku. Stopień zbieżności planu sukcesji w konkretnym przypadku przedsiębiorstwa rodzinnego z zaprezentowanym modelem-benchmarkiem pozwoli prognozować efektywność i powodzenie transferu międzypokoleniowego. 


\section{Antropologiczne struktury rodzin jako determinanty procesu planowania i implementacji sukcesji zarządzania w małych przedsiębiorstwach rodzinnych}

Naukową podstawą wyjaśnienia relatywnie niskiej liczby pomyślnych sukcesji przedsiębiorstw rodzinnych może być antropologiczna koncepcja struktury rodziny i jej wpływu na zachowania członków rodziny. Cechą wyróżniającą przedsiębiorstwo rodzinne od pozostałych jest wpływ systemu określonej rodziny na system przedsiębiorstwa, a w szczególności na jego kulturę organizacyjną i system zarządzania.

Berger i Luckmann ${ }^{4}$ - twórcy teorii socjalizacji - twierdzą, że każdy człowiek tworzy i rozwija własną koncepcję rzeczywistości w czasie, która w dużym stopniu determinuje jego późniejsze zachowanie, percepcję otaczającego świata, pełnienie funkcji zawodowych, w tym menedżerskich. Podstawowe i pierwotne procesy socjalizacyjne przebiegają z udziałem instytucji, które mają największy wpływ na wychowanie dziecka, i które same ewoluują bardzo powoli. Należą do nich: rodzina, szkoła i Kościół czy media. Na etapie życia dorosłego i zawodowego człowiek jest pod wpływem instytucji należących do systemu politycznego, prawnego, finansowego, gospodarczego, wyznaczających jego swobodę działania.

Z uwagi na silne więzi emocjonalne rodzina jest instytucją najważniejszą w całym procesie socjalizacyjnym. Członkowie rodziny, zaangażowani w prowadzenie wspólnego biznesu, przenoszą rodzinne wzorce zachowań i wartości do przedsiębiorstwa. Wyjątkowa kultura organizacyjna przedsiębiorstw rodzinnych jest rezultatem przeniesienia stylu „rządzenia w rodzinie” do zarządzania przedsiębiorstwem.

Antropologia rozwinęła koncepcję struktury rodziny w celu opisania organizacji, reguł i stylu zarządzania nią. Może być ona wykorzystana do wyjaśniania specyfiki w zarządzaniu przedsiębiorstwem rodzinnym. Todd 5 określa strukturę rodziny jako względnie trwały system interakcji zachodzących w ramach rodziny, który kształtuje postrzeganie rzeczywistości przez każdego jej członka. Istnieje kilka typologii struktur rodziny - w zależności od przyjętych kryteriów. Todd, na podstawie wcześniejszych prac z zakresu antropologii rodzinnej, własnych

4 P.L. Berger, T. Luckmann, The Social Construction of Reality, Penguin Books, New York 1991.

5 E. Todd, The Explanation of Ideology: Family Structures and Social Systems, Basil Blackwell, New York 1985. 
badań i analiz historycznych, zidentyfikował siedem różnych typów struktur rodzinnych na świecie, posługując się następującymi zmiennymi (kryteriami):

- stopniem integracji rodziny i podporządkowania międzypokoleniowego (kryterium charakteryzujące relacje rodzice - dzieci), mierzonym faktem tworzenia wspólnego gospodarstwa domowego (lub zamieszkiwania w bezpośrednim sąsiedztwie) lub faktem usamodzielnienia się dzieci, tworzenia przez nie odrębnych gospodarstw domowych;

- zasadą podziału majątku rodzinnego (równość/nierówność w zakresie traktowania sukcesorów/dzieci);

- zasadą wyboru partnera na małżonka dziecka (zwyczaj, rodzice, pełna swoboda);

- relacjami między małżonkami (egzogamia/endogamia).

Największe znaczenie dla kultury europejskiej mają struktury rodziny powstałe $\mathrm{z}$ kombinacji dwóch pierwszych zmiennych zastosowanych przez Todda: stopnia integracji rodziny i podporządkowania międzypokoleniowego (uzależnienie dzieci od rodziców/swoboda myśli i czynów) oraz zasady podziału majątku rodziny (równość/nierówność w zakresie traktowania dzieci). Zakłada się, że rodziny w tym kręgu kulturowym są egzogamiczne i w zakresie wyboru współmałżonka dominuje swoboda, chociaż w rodzinie autokratycznej wielopokoleniowej głowa rodziny akceptuje lub nie ten wybór.

Poniżej autor prezentuje własne charakterystyki możliwych typów struktury rodziny na podstawie ich profili proponowanych przez Todda, Hansona ${ }^{6}$, Schultenovera ${ }^{7}$, Very'ego i Raytchevą ${ }^{8}$.

W przypadku rodzin nuklearnych (nazwa nadana przez Todda - oznacza brak wielopokoleniowości rodziny) arbitralnych dwupokoleniowych aktywa rodzinne mają jednego właściciela (jest nim głowa gospodarstwa domowego), nie ma precyzyjnych reguł dziedziczenia, arbitralne testamenty są powszechną praktyką w tej dziedzinie, dorosłe dzieci nie są zachęcane do mieszkania z rodzicami, a wręcz przeciwnie - oczekuje się od nich zakładania własnych, niezależnych gospodarstw domowych, a dzieci same do tego dążą. Niepewność co do dziedziczenia oraz silne poczucie wolności myśli i czynów oraz odpowiedzialności za swój los sprzyjają indywidualizmowi w zachowaniach przedstawicieli młodej generacji, rozwojowi ich orientacji przedsiębiorczej i powielaniu w wielu przypadkach modelu „pracy na swoim” - według

6 K.C. Hanson, Kinship, „Biblical Theology Bulletin” 1994, no. 24, s. 183-194.

7 D.G. Schultenover, An Anthropological View of the Modern Crisis, „Journal of Religion \& Society" 1999, vol. 1, s. 201-236.

8 P. Very, S. Raytcheva, Family Structures, Family Firms and Succession: Some Insights from Anthropology, International Council for Small Businesses 47th World Conference, Puerto Rico 2002. 
wzorca swoich rodzin przedsiębiorczych. Panuje powszechna opinia, że ludzie nie rodzą się na eksponowane stanowiska, lecz muszą na nie zapracować. Kultura tego typu rodzin nacechowana jest dużą tolerancją na różnice osobowościowe, światopoglądowe, zmiany, innowacyjne pomysły, a także elastycznością działania i orientacją na teraźniejszość. Członkowie takich rodzin nie przywiązują większej wagi do przeszłości, a świadomość nieuchronności w przyszłości (choroba, starość, śmierć) jest źródłem ich motywacji i aktywności zawodowej w teraźniejszości. Członkowie rodziny są odporni na stres, kierują się zdrowym rozsądkiem, pojmują władzę w kategoriach kompetencji, a nie w kategoriach płci (maskulinizm) czy przynależności do grupy społecznej (rodzina, partia etc.). Jednocześnie panuje w tej kulturze egocentryzm. Dobro i zło identyfikuje się w pierwszej kolejności na podstawie interesu jednostki, potem uwzględnia się interes grupy czy ogółu. Ambicje korporacyjne wywołują agresję i pęd do pokonywania kolejnych szczebli kariery zawodowej, a przekonanie, że cel uświęca środki, jest powszechne. Przynależność do grupy społecznej wynika przede wszystkim z perspektyw i korzyści dla jednostki, a nie z faktu bycia jednostką społeczną. Socjalizacja młodego pokolenia w szkołach w regionach, gdzie dominuje ten typ kultury, odbywa się według zasady, że dzieci rodzą się moralne i dobre. Nie można ingerować w ich osobowość, ekspresję, mają one być przygotowane do funkcjonowania zgodnie ze swoją naturą. Akcentuje się wagę kształtowania takich kompetencji jak niezależność, przedsiębiorczość, samodzielność. Rodziny nuklearne arbitralne dwupokoleniowe dominują w Wielkiej Brytanii, USA i Holandii.

\begin{tabular}{|c|c|c|}
\hline $\begin{array}{r}\text { Relacje } \\
\text { intrapokoleniowe }\end{array}$ & Równość & Nierówność \\
\hline $\begin{array}{c}\text { Relacje } \\
\text { międzypokoleniowe }\end{array}$ & Rodeżność \\
i podporządkowanie & $\begin{array}{c}\text { wielopokoleniowe } \\
\text { wing wólnotowe } \\
\text { i czynów }\end{array}$ & $\begin{array}{c}\text { Rodziny autorytarne } \\
\text { wielopokoleniowe }\end{array}$ \\
\hline $\begin{array}{c}\text { Rodziny nuklearne } \\
\text { egalitarne } \\
\text { dwupokoleniowe }\end{array}$ & $\begin{array}{c}\text { Rodziny nuklearne } \\
\text { arbitralne } \\
\text { dwupokoleniowe }\end{array}$ \\
\hline
\end{tabular}

Rysunek 1. Struktury rodziny według kryteriów i typologii Todda Źródto: opracowanie własne. 
Rodziny nuklearne egalitarne dwupokoleniowe mają cechy zbliżone do rodzin arbitralnych dwupokoleniowych, jednak dziedziczenie aktywów rodzinnych odbywa się na zasadzie równości gwarantowanej prawem. Dzieci wzrastają w przekonaniu, że mogą polegać na innych: rodzicach, rodzinie i państwie. Majątek rodziny dzieli się na równe części pomiędzy potomków płci męskiej, którzy zakładają własne, odrębne gospodarstwa domowe. Zasada równości w dziedziczeniu wcześniej nie dotyczyła kobiet, jednak w czasach obecnych stosuje się ją, z pewnymi ograniczeniami, do wszystkich potomków, bez względu na płeć. Podobnie jak w poprzedniej strukturze rodziny obserwuje się tolerancję w zakresie norm społecznych czy moralnych. Ten typ rodziny jest bardziej różnorodny w porównaniu do opisywanego wyżej. Rodziny nuklearne egalitarne dwupokoleniowe dominują w północnej i centralnej Francji, północnej części Włoch, w Hiszpanii oraz Grecji.

Rodziny wspólnotowe wielopokoleniowe (wspólnoty patriarchalne) są zorganizowane wertykalnie. Majątek rodzinny należy do wszystkich członków, ale zarządzany jest jednoosobowo. Synowie z własnymi rodzinami mieszkają wspólnie (tworzą wspólne gospodarstwo domowe) z rodzicami aż do ich śmierci, następnie zakładają odrębne gospodarstwa domowe. Wspólnoty patriarchalne wyróżniają się silną tożsamością grupową, przywiązaniem do tradycji, centralnym „rządzeniem”, silnym poczuciem podporządkowania, posłuszeństwa, hierarchii, ale i równości wśród młodszego pokolenia, niechęcią do zmian i dużą wrażliwością na stres. Zdarza się, że rodzice aranżują małżeństwa dzieci. Do pełnienia funkcji przywódczych predysponowani są mężczyźni (maskulinizm). Wspólnoty, w przeciwieństwie do rodzin dwupokoleniowych, żyją przeszłością (historia rodziny, tradycja i rodzinne zwyczaje) oraz przyszłością. Myślenie strategiczne nastawione na kontynuację przedsięwzięć rodzinnych jest zatem naturalną właściwością tego typu rodzin, które przeważają w centralnych Włoszech, Rosji i Chinach. Wspólnoty patriarchalne dominowały także w Cesarstwie Rzymskim. Rodziny autorytarne wielopokoleniowe przypominają wertykalne struktury patriarchalne - „monarchie absolutne”. Głowa rodziny, najczęściej mężczyzna, skupia w swoich rękach pełnię władzy, którą sprawuje niepodzielnie, apodyktycznie i do samego końca. Członków rodziny obowiązuje przestrzeganie surowych norm społecznych i moralnych, bezwzględne posłuszeństwo, lojalność i szacunek wobec głowy rodziny. Obowiązkiem rodziny jest zapewnienie kontynuacji tradycji i powiększanie jej zasobów, a zatem interes grupy jest ważniejszy od interesu jednostki. W tej kulturze nie toleruje się odmienności i różnorodności w myśleniu i działaniu, radykalnych zmian i nowych idei, upatrując w nich zagrożenia dla istniejącego porządku i tożsamości grupy. Konformizm, z jednej strony dyscyplina i kontrola formalna, a z drugiej brak zaufania, strach i niepewność dają podstawę do utożsamiania takiej struktury rodziny $\mathrm{z}$ systemem neurotycznym, sprzecznym wewnętrznie. 
Wbrew pozorom żony decydentów zajmowały zawsze wyjątkową pozycję w strukturze rodziny, chociaż o niczym nie decydowały formalnie ani nie partycypowały w masie spadkowej. Pełniły i pełnią funkcję opiekunek „domowego ogniska”, o dużej randze kulturowej. W tym przypadku majątek rodzinny przejmuje jeden z synów, wskazany arbitralnie przez głowę rodziny (najstarszy lub najmłodszy), który tworzy swoje gospodarstwo domowe $z$ rodzicami. Przejęcie pełnej władzy nad aktywami rodzinnymi przez jednego sukcesora gwarantuje integralność, stabilność i ciągłość dorobku poprzednich pokoleń i tradycji rodzinnych. Pozostałe rodzeństwo musi odejść i starać się budować własne gospodarstwa domowe bez większego wsparcia od rodziny. Z przekazów historycznych wiadomo, że los dla nich nie zawsze był łaskawy - mężczyźni zaciągali się do wojska, wstępowali do seminariów duchowych, a kobiety do zakonów. Wśród rodzeństwa dominuje zatem rywalizacja o pozycję sukcesora tradycji i aktywów majątkowych rodziny. Ten typ rodziny występuje w zachodnich landach Niemiec, w Szwecji, Norwegii, Irlandii, Japonii oraz Korei.

Struktura rodziny, a w jej ramach sposób socjalizacji młodego pokolenia rodzą istotne implikacje dla procesu planowania sukcesji w przedsiębiorstwach rodzinnych. W rodzinach nuklearnych dwupokoleniowych istnieje potencjalne zagrożenie nieplanowania sukcesji rodzinnej w przedsiębiorstwie z uwagi na swobodę wyborów życiowych młodych, którzy kulturowo zorientowani są na usamodzielnienie się i budowanie odrębnych gospodarstw rodzinnych. W wielu przypadkach młodzi nie są zainteresowani przejęciem przedsiębiorstwa rodzinnego. Dzięki socjalizacji w środowisku przedsiębiorczym prawdopodobieństwo, że przedstawiciele młodego pokolenia rodzin nuklearnych założą własne przedsiębiorstwa i powielą model kariery zawodowej swoich rodziców, jest znaczne. Seniorzy, którzy mają długofalową wizję biznesu, przekonanie co do jego szans rozwojowych i chcieliby kontynuacji pokoleniowej, powinni podjąć dialog z wybranymi przedstawicielami młodego pokolenia w ramach socjalizacji, z odpowiednim wyprzedzeniem czasowym, w celu przekonania ich do swojej propozycji, wykształcenia u nich pożądanych kompetencji i zaplanowania transferu. Przejęcie biznesu rodzinnego nie musi oznaczać rezygnacji z wolności myśli i czynów czy konieczności tworzenia wspólnego gospodarstwa domowego z rodzicami. Kontynuacja przedsięwzięcia biznesowego pozwala zaspokoić potrzeby przedsiębiorcze, samorealizacji młodych i wiąże się z mniejszym ryzykiem niż tworzenie biznesu od podstaw.

W rodzinach wielopokoleniowych proces planowania sukcesji jest łatwiejszy w porównaniu do rodzin dwupokoleniowych, gdyż kulturowo wszyscy członkowie młodego pokolenia chcą być sukcesorami, co rodzi rywalizację i konflikty między nimi. Pokrewieństwo, preferencje seniora i wola kandydata są wystarczające do przejęcia przez tego drugiego władzy w przedsiębiorstwie rodzinnym, nawet 
jeśli nie ma stosownych kompetencji menedżerskich. W większych przedsiębiorstwach rodzinnych głowa rodziny planuje wykształcenie kandydata na sukcesora. Należy przypuszczać, że we współczesnych rodzinach autorytarnych młodzi, którzy nie zostali sukcesorami rodzinnymi, założą własne, niezależne przedsiębiorstwa, co wynika z procesu ich socjalizacji. W rodzinach wspólnotowych wszyscy członkowie młodego pokolenia partycypują w rodzinnej własności i mogą, jeśli chcą, pracować we wspólnym przedsiębiorstwie. Władza o charakterze demokratycznym jest przekazywana najczęściej wybranemu potomkowi męskiemu. Obecnie zamieszkiwanie we wspólnym gospodarstwie domowym dorosłych dzieci i ich rodzin z rodzicami nie jest powszechną praktyką. Głowa rodziny aranżuje potomkom ich odrębne gospodarstwa domowe, ale w bliskim sąsiedztwie od swojego, aby nie tracić kontroli nad nimi.

\section{Model efektywnej sukcesji zarządzania w średnich i dużych przedsiębiorstwach rodzinnych}

Antropologiczna koncepcja struktury rodziny może mieć także zastosowanie do wyjaśnienia procesów sukcesyjnych w dużych przedsiębiorstwach rodzinnych. Jednak z uwagi na wymagany poziom profesjonalizacji zarządzania, związany ze skalą i zakresem działania oraz potrzebą nowych kompetencji menedżerskich wynikających z warunków globalizacji, gospodarki 4.0 czy gospodarki opartej na wiedzy, planowanie i wdrażanie sukcesji zarządzania w takich przedsiębiorstwach musi przebiegać według formalnie wdrożonych procedur i pod nadzorem osób i organów niezależnych od wpływów rodziny. Autor, na podstawie dobrych praktyk zidentyfikowanych przez cztery ośrodki na świecie, wspomagające systemy zarządzania głównie dużych przedsiębiorstw rodzinnych, skonstruował model gwarantujący efektywną sukcesję zarządzania w większych podmiotach rodzinnych. Z uwagi na ograniczenia redakcyjne, nie przywołano tu szczegółowej metodologii badań, stosowanej przez indywidualne ośrodki, dokonano jedynie poglądowej prezentacji dobrych praktyk zidentyfikowanych przez nie, a dotyczących sukcesji zarządzania.

Od czterech dekad Cambridge Institute for Family Enterprise (US) ${ }^{9} \mathrm{w}$ ramach swojej misji doradczej i edukacyjnej zajmuje się wspieraniem procesów sukcesyjnych w przedsiębiorstwach rodzinnych. Wspólnie z rodzinami przedsiębiorczymi i zarządami przedsiębiorstw opracowuje plany sukcesyjne. Zgromadzone

9 P. Michaud, C. Collette, J.A. Davis, CEO Succession in the Family Business. A Better Plan for Success, Cambridge Institute for Family Enterprise, Cambridge 2017. 
doświadczenie pozwoliło instytutowi na zaprezentowanie wzorcowego modelu sukcesji zarządzania, który opiera się na czterech zasadach: stworzeniu koncepcji mapy przedsiębiorstwa (mapy szans zatrudnienia dla wszystkich członków rodziny właścicielskiej), proprzedsiębiorczej, promoralnej socjalizacji młodego pokolenia, obiektywizacji procesu sukcesji przez delegowanie uprawnień w tym zakresie radzie konsultacyjnej (organ zewnętrzny wobec rodziny właścicielskiej), dynamice sukcesji (dyscyplina i harmonogram transparentnego, niepospiesznego procesu sukcesji zarządzania). Model powstał jako odpowiedź na negatywne praktyki podejmowane w procesie planowania i implementacji sukcesji zarządzania w średniej wielkości przedsiębiorstwach rodzinnych.

Dennis Jaffe, jeden $\mathrm{z}$ pionierów konsultingu dedykowanego przedsiębiorstwom rodzinnym, szukał najbardziej efektywnego modelu planowania i implementacji sukcesji w wynikach badania stu dużych, wielopokoleniowych (co najmniej trzecie pokolenie rodziny sprawuje kontrolę) przedsiębiorstw rodzinnych w dwudziestu krajach $^{10}$. Ponieważ są to przedsiębiorstwa, które od co najmniej stu lat pozostają w rękach rodzin założycielskich, rosną i rozwijają się modelowo, uznano, że ich praktyki sukcesyjne powinny stanowić przewodnik dla wszystkich przedsiębiorstw rodzinnych zmagających się z transferem zarządzania. Jaffe nazywa rodziny kontrolujące te przedsiębiorstwa rodzinami generatywnymi, ponieważ generują one wartości i normy w sposób ciągły przez kolejne pokolenia i dzięki temu budują silną infrastrukturę moralno-etyczną rodziny i biznesu. Autor niniejszego opracowania we wcześniejszych publikacjach opisywał infrastrukturę moralną jako istotny element kapitału społecznego rodziny, jako narzędzie kontroli społecznej w przedsiębiorstwie oraz wyjaśniał mechanizm budowania tej infrastruktury poprzez komunikację między członkami rodziny, opartą na dialogu partnerskim. Infrastruktura moralna, kumulowana przez kolejne pokolenia, jest naturalnym środowiskiem socjalizacji młodego pokolenia oraz źródłem budowania silnych relacji interpersonalnych z wewnętrznymi i zewnętrznymi społecznościami interesariuszy. Dobre praktyki dotyczące sukcesji zarządzania zidentyfikowane przez Jaffego i opublikowane w wydawnictwie Forbesa jako wzorzec postępowania dla wszystkich dużych firm rodzinnych oparte są na następujących zasadach: ciągłości międzypokoleniowego procesu generowania wspólnych wartości i norm, odporności na kryzysy, transparentności, profesjonalizacji zarządzania, międzypokoleniowemu zaangażowaniu i współpracy, ofercie zatrudnienia w szeroko rozumianym przedsiębiorstwie dla członków nowego pokolenia, filantropii, społecznej odpowiedzialności.

10 D. Jaffe, If You Want Your Family Business To Last Several Generations, FORBES, 2018, https:// www.forbes.com/sites/dennisjaffe/2018/08/30/if-you-want-your-family-business-to-last-se veral-generations/\#7e756d4a7c16 (dostęp: 20.06.2019). 
Spencer Stuart jest jedną z wiodących na świecie amerykańskich firm konsultingowych, poszukujących najlepszych praktyk w zakresie przywództwa w organizacjach, w tym planowania sukcesji zarządzania w przedsiębiorstwach rodzinnych. Na podstawie wieloletniego doświadczenia ze współpracy z praktyką gospodarczą oraz kontaktów z liderami przedsiębiorstw rodzinnych na świecie firma ta zidentyfikowała model udanych sukcesji zarządzania dla średnich i dużych przedsiębiorstw ${ }^{11}$. Składa się on $\mathrm{z}$ następujących komponentów: procesowego podejścia do sukcesji, gwarantującego ciągłość zarządzania; profilu kompetencyjnego sukcesora, sporządzonego na podstawie planów strategicznego rozwoju przedsiębiorstwa i pożądanych kompetencji w sektorze; niezależnej rady nadzorczej/konsultacyjnej i rady rodziny - jako organów odpowiedzialnych za przygotowanie i wdrażanie planu sukcesji zarządzania; poszerzenia spektrum potencjalnych kandydatów na sukcesora o profesjonalistów spoza rodziny; wsparcia nowego lidera przez interesariuszy wewnętrznych.

Claudio Fernández-Aráoz pracuje dla globalnej szwajcarskiej firmy konsultingowej Egon-Zehnder, prowadzącej badania w zakresie zarządzania i przywództwa w dużych przedsiębiorstwach. Jest także członkiem zarządu Harvard Business School. Na podstawie badań pięćdziesięciu dużych globalnych przedsiębiorstw rodzinnych ustalił efektywny model sukcesji zarządzania, który zwiększa prawdopodobieństwo utrzymania kontroli rodziny, kontynuacji ich rozwoju w dłuższej perspektywie czasu ${ }^{12}$. Wszystkie badane firmy stosowały następujące zasady:

- nadzór właścicielski w postaci profesjonalnej rady nadzorczej neutralizującej praktyki nepotyczne;

- zasada grawitacji rodziny i jej wartości (wykorzystywanie kapitału społecznego rodziny);

- możliwość wyboru na nowego „przywódcę” kandydata spoza rodziny;

- obecność formalnej procedury selekcji kandydata na sukcesora zarządzania.

Badane przedsiębiorstwa osiągały przychody na poziomie co najmniej $500 \mathrm{mln}$ euro, pochodziły z różnych sektorów Ameryki Północnej i Południowej, Europy oraz Azji. Wywiady prowadzone były z ich rodzinnymi i nierodzinnymi przywódcami.

Duże firmy rodzinne nie mają szans właściwie zarządzać talentami wewnętrznymi (rodzinnymi i nierodzinnymi) lub przyciągać zewnętrznych profesjonalistów

11 Spencer Stuart, Beyond the family tree: succession planning for family businesses, 2010, https://www.spencerstuart.com/ /media/pdf\%20files/research\%20and\%20insight $\% 20$ $\mathrm{pdfs} /$ beyond-the-family-tree-succession-planning-for-family-businesses_13jun2013.pdf (dostęp: 20.06.2019).

12 C. Fernández-Aráoz, S. Iqbal, J. Ritter, Leadership Lessons from Great Family Businesses, „Harvard Business Review” 2015, vol. 93, no. 4, s. 45-60. 
bez wdrożenia dobrych praktyk corporate governance, które rozdzielają system rodziny właścicielskiej od systemu biznesu i zapewniają silny nadzór profesjonalnego organu w postaci rady nadzorczej lub rady konsultacyjnej nad zarządem. Prawie $25 \%$ badanych liderów spoza rodziny wymieniało następujące obawy dotyczące corporate governance przed rozpoczęciem pracy w przedsiębiorstwie rodzinnym: niepewność co do poziomu autonomii lidera, ukryte intencje i zamiary rodziny właścicielskiej, brak dynamiki działań operacyjnych i w końcu zagrożenia nepotyczne i irracjonalizm podejmowanych decyzji. Przez rady nadzorcze lub konsultacyjne/doradcze składające się średnio z dziewięciu członków kontrolowane było $94 \%$ badanych przedsiębiorstw rodzinnych. Były one reprezentowane przez rodziny właścicielskie w 46\% średnio w Europie, w 28\% w obu Amerykach i w 26\% w Azji. Stwierdzono istotne rozdzielenie systemów rodziny i biznesu w tych przedsiębiorstwach.

Nałożenie na siebie czterech prezentowanych wersji modelu sukcesji w dużych przedsiębiorstwach rodzinnych prowadzi do stworzenia jednego, holistycznego modelu, który może i powinien być benchmarkiem dla planów i działań sukcesyjnych konkretnych przedsiębiorstw rodzinnych. Jego zasadnicza struktura obejmuje następujące etapy i procesy:

Etap przedsukcesyjny:

- Socjalizacja młodego pokolenia rodziny w kierunku orientacji przedsiębiorczej, kształcenia potrzeby profesjonalizmu w aktywności zawodowej, menedżerskiej, biznesowej oraz kształcenia inteligencji moralnej i emocjonalnej.

- Kreowanie szans zatrudnienia dla wszystkich członków młodego pokolenia w przedsiębiorstwie rodzinnym i zachęcanie młodych do ich wykorzystywania poprzez prezentację im mapy szeroko rozumianego przedsiębiorstwa rodzinnego ze stanowiskami do objęcia.

- Stworzenie przez seniorów platformy do komunikacji międzypokoleniowej, opartej na dialogu partnerskim, w celu zachowania ciągłości procesu generowania norm i wartości w rodzinie, a później ewentualnie w biznesie, oraz modyfikacji wizji biznesu i wizji rodziny w nim, które będą atrakcyjne dla młodego pokolenia (rodziny generatywne).

\section{Etap sukcesyjny:}

- Zapewnienie niezależności radzie nadzorczej lub w przypadku jej braku radzie konsultacyjnej/doradczej, której obowiązkiem będzie wprowadzenie formalnej procedury sukcesyjnej w przedsiębiorstwie, o wysokim priorytecie i dyscyplinie przestrzegania, gwarantującej selekcję nowego lidera spośród najlepszych kandydatów rodzinnych i spoza rodziny, na podstawie kryteriów profilu kompetencyjnego. Rada nadzorcza wyznacza komitet sukcesyjny, który wykonuje czynności techniczne przewidziane w procedurze. 
- Pielęgnowanie zasady grawitacji rodziny i jej wartości w celu utrzymania i powiększania zasobów kapitału społecznego w przedsiębiorstwie, będących źródłem przewagi konkurencyjnej nad podmiotami nierodzinnymi.

- Ocena dopasowania nierodzinnego kandydata na nowego lidera do kultury organizacyjnej przedsiębiorstwa stanowi dodatkowe kryterium jego wyboru.

- Opracowanie strategii wycofania się lidera seniora z zarządzania.

- Zarządzanie rozwojem kompetencyjnym kandydata na lidera.

Etap posukcesyjny:

- Częste oceny aktywności i wyników nowego lidera w okresie próbnego zatrudnienia przez niezależną radę.

- Demonstrowanie poparcia dla pomysłów i działań sukcesora przez ustępującego lidera oraz pozostałych członków rodziny i zarządu.

- Wykorzystywanie dźwigni kompetencyjnej międzypokoleniowej (wykorzystywanie doświadczenia i wpływów ustępującego seniora przez nowego lidera).

\section{Podsumowanie}

$\mathrm{Na}$ świecie istnieją rozwiązania, dobre praktyki, modele, istotnie zwiększające prawdopodobieństwo powodzenia sukcesji zarządzania w przedsiębiorstwach rodzinnych, która pozwoli na kontynuację tradycji rodzinnych i nieprzerwane kumulowanie zasobu niematerialnego - kapitału społecznego wewnętrznego i zewnętrznego, będącego jednym z kluczowych źródeł przewagi konkurencyjnej biznesu w XXI wieku.

Ważną konkluzją wynikającą z przeglądu literatury i rozważań nad efektywnym modelem sukcesyjnym w przedsiębiorstwach rodzinnych jest nieuchronność przekształcania się rodzin menedżerskich, aktywnie uczestniczących w zarządzaniu, w rodziny właścicielskie, ograniczające się tylko do funkcji nadzorczych i kontrolnych w wielopokoleniowych, dużych przedsiębiorstwach rodzinnych. Efekt „grawitacji rodziny i jej wartości” w przedsiębiorstwie pozwala utrzymać wyjątkową kulturę organizacyjną, opartą na infrastrukturze moralnej rodziny, nawet w warunkach wycofania się członków rodziny właścicielskiej z aktywnego przywództwa. Wartości rodziny właścicielskiej nadal mogą wyznaczać wzorce zachowań w organizacji i poza nią.

Upieranie się przy wąskiej definicji przedsiębiorstwa rodzinnego, w którym rodzina dominuje jednocześnie w zarządzaniu i strukturze własności, na potrzeby badań i generowania wiedzy na temat funkcjonowania podmiotów rodzinnych jest nieuzasadnione i niewłaściwe, gdyż takie podejście ogranicza je tylko do sektora 
małych i najwyżej średnich przedsiębiorstw i stoi w jawnej sprzeczności z paradygmatem wzrostu i rozwoju organizacji w naukach o zarządzaniu i jakości. Wąska definicja przedsiębiorstwa rodzinnego jest anachroniczna, szkodliwa dla jego wizerunku, utrudniająca efektywne procesy sukcesyjne gwarantujące bezpieczeństwo finansowe dla kolejnych pokoleń rodziny. Autor postuluje zatem przyjęcie i popularyzację następującej definicji przedsiębiorstwa rodzinnego:

Przedsiębiorstwo rodzinne to organizacja gospodarcza, której kultura organizacyjna kształtowana jest przez system wartości i norm rodziny właścicielskiej/ założycielskiej, a siła wpływu tego systemu na kulturę organizacyjną wyznacza następujące jego typy:

A) przedsiębiorstwo, w którym rodzina pełni kluczowe funkcje zarządzania13 i dominuje ${ }^{14}$ w strukturze jego własności;

B) przedsiębiorstwo, w którym rodzina rezygnuje z pełnienia kluczowych funkcji zarządzania, ale dominuje w strukturze jego własności, dzięki czemu sprawuje kontrolę nad zarządem;

C) przedsiębiorstwo, w którym rodzina pełni kluczowe funkcje zarządzania, ale nie ma bezwzględnej lub względnej większości w strukturze jego własności.

Bibliografia

Berger P.L., Luckmann T., The Social Construction of Reality, Penguin Books, New York 1991.

Chrisman J., Chua J.H., Sharma P., Current trends and future directions in family business management studies: Toward a theory of the family firm, „Coleman White Paper Series”, Coleman Foundation and USA Association of small Business and Entrepreneurship, Madison 2003, s. 1-60.

Chua J.H., Chrisman J.J., Sharma P., Succession and non-succession concerns of family firms and agency relationship with nonfamily managers, „Family Business Review” 2003, vol. 16(2), s. 221-235.

Fernández-Aráoz C., Iqbal S., Ritter J., Leadership Lessons from Great Family Businesses, „Harvard Business Review" 2015, vol. 93, no. 4, s. 45-60.

Habbershon T.G., Williams M.L., A resource-based framework for assessing the strategic advantages of family firms, „Family Business Review” 1999, vol. 12(1), s. 1-25.

Habbershon T.G., Williams M.L., Macmillan I.C., A unified systems perspective of family firm performance, „Journal of Business Venturing” 2003, vol. 18(4), s. 451-465.

Hanson K.C., Kinship, „Biblical Theology Bulletin” 1994, no. 24, s. 183-194.

Hoffman J., Hoelscher M., Sorenson R., Achieving sustained competitive advantage: A family capital theory, „Family Business Review” 2006, vol. 19(2), s. 135-145.

13 Kluczowe funkcje zarządzania oznaczają bycie liderem.

14 Dominacja oznacza posiadanie kontrolnego pakietu akcji w przypadku spółek giełdowych lub większości we własności w przypadku przedsiębiorstw prywatnych (niepublicznych). 
Jaffe D., If You Want Your Family Business To Last Several Generations, FORBES 2018, https://www .forbes.com/sites/dennisjaffe/2018/08/30/if-you-want-your-family-business-to-last-sever al-generations/\#7e756d4a7c16 (dostęp: 20.06.2019).

Michaud P., Collette C., Davis J.A., CEO Succession in the Family Business. A Better Plan for Success, Cambridge Institute for Family Enterprise, Cambridge 2017.

Popczyk W., The structure and creating of family social capital in business, [w:] New Challenges of Economic and Business Development, University of Latvia, Riga 2018, s. 676-685.

Schultenover D.G., An Anthropological View of the Modern Crisis, „Journal of Religion \& Society” 1999, vol. 1, s. 201-236.

Spencer Stuart, Beyond the family tree: succession planning for family businesses, 2010, https:// www.spencerstuart.com/ /media/pdf\%20files/research\%20and\%20insight\%20pdfs/be yond-the-family-tree-succession-planning-for-family-businesses_13jun2013.pdf (dostęp: 20.06.2019).

Todd E., The Explanation of Ideology: Family Structures and Social Systems, Basil Blackwell, New York 1985.

Very P., Raytcheva S., Family Structures, Family Firms and Succession: Some Insights from Anthropology, International Council for Small Businesses 47th World Conference, Puerto Rico 2002.

Wood C., The Surprising Stats about Succession in Family Business, „All Strategy” 2018, https:// www.allstrategy.net/the-surprising-stats-about-succession-in-family-business/ (dostęp: 1.06.2019).

\section{Streszczenie}

Jednym z najważniejszych kluczowych czynników rozwoju i wzrostu przedsiębiorstw rodzinnych jest zaplanowanie i implementacja sukcesji zarządzania. Ten wymagający i skomplikowany proces w zdecydowanej większości przypadków kończy się niepowodzeniem i utratą niematerialnego zasobu w postaci kapitału społecznego wewnętrznego i zewnętrznego, którego nośnikiem jest rodzina właścicielska, a który jest źródłem przewagi konkurencyjnej w XXI wieku. Celem rozdziału jest identyfikacja koncepcji naukowych, które pomogą zrozumieć powody niepowodzeń sukcesyjnych w firmach rodzinnych, oraz prezentacja najlepszych rozwiązań sukcesyjnych na świecie, zwiększających prawdopodobieństwo transferu międzypokoleniowego (lub pozarodzinnego) zarządzania w małych, średnich i dużych przedsiębiorstwach rodzinnych.

Słowa kluczowe: przedsiębiorstwo rodzinne, sukcesja zarządzania, model sukcesji, struktura rodziny

\section{Concepts and models of management succession in family enterprises}

\section{Abstract}

One of the most important key factors for the development and growth of family businesses is the planning and implementation of management succession. This demanding and complicated process in the vast majority of cases ends in failure and loss of an intangible resource in the form of internal and external social capital, the carrier of which is the ownership family and which is the source of competitive advantage in the 21 st century. The purpose of the article is to identify 
scientific concepts that will help understand the reasons for succession failures in family businesses and to present the best succession solutions in the world that increase the likelihood of intergenerational (or non-family) management transfer in small, medium and large family businesses in the 21 st century.

Keywords: family enterprise, management succession, succession model, family structure 